\title{
Ghanaian Educational Institutions' Capacity for, and Approach to, ICT Pedagogical Integration
}

\author{
Kofi Mereku
}

University of Education, Winneba

P.O. Box 25, winneba, Ghana

E-mail:kofi.mereku@yaboo.com

\begin{abstract}
The paper reports some of the findings of Ghana's participation in the Pan African Research Agenda on the Pedagogical Integration of ICT. The study examines Ghanaian educational institutions' capacity for, and approach to, ICT pedagogical integration. A Junior High School, three Senior High schools and a Teacher Education University are sampled by a University of Education Winneba (UEW) based research team according to given guidelines. The study combines document analysis and survey techniques with the use of structured questionnaire, class observation checklists and interview schedules to collect qualitative and quantitative data which have been uploaded onto an open online observatory at www.observatoiretic.org. The results indicate that some attempts had been made by the Ministry of Education to formalize the teaching of ICT literacy and encourage its integration into the teaching and learning process. Nonetheless, very little integration is observed in teaching and learning in schools. This is found to be due in part to inefficiencies in the design of the curriculum and partly to the inadequate ICT resources (both material and human) available. It is recommended that the Ministry of Education should review the curricula at various levels to ensure ICT pedagogical integration in their implementation and make available sufficient resources for ongoing training and support for teachers to model the new pedagogies and tools for learning.
\end{abstract}

Keywords: ICT literacy, ICT pedagogical integration, Inhibiting factors.

\section{Introduction}

One major requirement of Ghana's recent educational reforms launched in 2007 was to ensure that all students in pre-tertiary institutions in Ghana acquire basic ICT literacy skills (including internet use) and apply these not only in their studies but also in a variety of ways in their everyday life activities (CRDD, 2007a, b and c). The Pan-African Agenda on Pedagogical Integration of ICT project, therefore, came at an opportune time, that is, at a time that the government had launched a new educational reform which emphasized the development of ICT literacy in learners as well as the pedagogical integration of ICT into the educational system.

Even though computer technology use for teaching and learning is gaining acceptance in education globally, in Ghana, efforts to use ICT in education began to receive governments' attention only recently. Ghana's recent participation in an international survey which was used to rate the ICT Development Indices (IDI) of the participating countries revealed that the country ranked between $100^{\text {th }}$ and $140^{\text {th }}$ position out of 154 countries surveyed (MOE, 2009). This indicates that Ghana, like many African countries, still lags behind in ICT development and ICT literacy, that is, 'the capacity to apply ICT in various areas of human life' (Markauskaite 2006) which includes teaching in schools.

Leu et al (2004) contend that ICT literacy has two important aspects - ICT tools and strategic knowledge, which are central for any type of literacy. The former refers to the use of basic ICT application programs or the operation of ICT. The second aspect, strategic knowledge, refers to such abilities as inquiring, identifying, creating, communicating and evaluating by means of ICT. Today, ICT curricula in many parts of the world require students to have the opportunity not only to operate ICT but also to develop strategic knowledge or what Lehmann (2007) described as 'global knowledge'. According to Lehmann (2007), global knowledge in one's discipline or globalization literacy' is the knowledge which the 
globally curious and alert (that is, educated) person should be able to have.

For Ghana and Africa as a whole, to fully integrate ICT into teaching and learning there is the need for frequent collection and analysis of data on ICT usage. The PanAfrican Research Agenda on the Pedagogical Integration of ICT (usually referred to as 'PanAf') research project was initiated in 2006 to support initiatives in African countries to integrate ICT into teaching and learning through the frequent collection and analysis of data on ICT usage. The project was carried out by national research teams from the Educational Research Network for West And Central Africa (ERNWACA). The main research goal of the PanAf project was for one in this regard to better understand how the pedagogical integration of ICT can improve the quality of teaching and learning in educational systems of participating African countries (ERNWACA, 2006).

\section{Methodology}

The national research team based in UEW sampled educators and learners from five schools/institutions according to given guidelines. The sample reported in this paper constituted 38 educators including school administrators and 80 students. The study combined document analysis and survey techniques by means of structured questionnaire, class observation checklists and interview schedules to collect qualitative and quantitative data which had been uploaded onto an open online observatory at www.observatoiretic.org. The survey was carried between November and January 2009. The data collected, and reports generated from the data, were validated by a National Committee of educational experts, which was formed for this purpose.

\section{Findings}

\subsection{ICT curriculum and pedagogical integration}

The 2007 education reforms in Ghana led to the introduction of studies in Core ICT in all Primary and Junior and Senior High schools in the country (CRDD, 2007a; CRDD, 2007b). Furthermore, an ICT course is now taught as an elective subject in high schools (CRDD, 2007c). In addition, the national curricula for the various subjects reviewed in 2007 contain statements about the use of ICT in teaching and learning. But analysis carried out on the national
ICT curricula indicated that the curricula emphasize the development of students' skills in the operation of ICT and not necessarily the development of their strategic knowledge or what Lehmann (2007) described as 'global knowledge'.

In the Ghanaian educational system, very little is being done to develop strategic knowledge because the curriculum gives too much attention to activities which lead mainly to the acquisition of knowledge and skills in the use of ICT tools. The curriculum gives little attention to learning experiences required for students to develop strategic knowledge. It makes teachers to provide little opportunity for pupils to engage in activities that will enable them to use or apply concepts to solve problems, reason critically, creatively, and practically; to connect ideas, people and realms of life; and to learn how to learn. It can be argued, therefore, that though there was rhetoric in the introduction of the curriculum materials on the use of ICT in teaching and learning which could lead to the development of students' strategic knowledge, the analysis revealed that the learning/teaching activities that would encourage the development of such knowledge were not included.

\subsection{ICT resources and its use in classrooms}

It is observed that all high schools and some primary schools have computers. A few have some forms of computer laboratories where teaching of ICT takes place; However their use is limited by such factors as the computers breaking down easily because of lack of air-conditioners, unstable electrical power supply, virus infections and poor maintenance culture . None of the computer labs observed is networked and only four computers in one of the schools have Internet connectivity. The ratio of students (and educators) to computers per institution is found to be very low. At the Senior High School level, there is an average of about 30 students to a computer and 50 students to a computer at the tertiary level.

The results also show that only teachers of Core ICT and, to a limited extent, SHS Science teachers indicate that they use ICT for teaching and learning purposes. The ICT teachers teach the use of ICT tools like the Microsoft Office suite, Encarta Encyclopedia, the Internet, and typing software in their instructional activities. The few teachers who claim they use ICT for their learning and preparation for teaching also agree that they do not use ICT for lesson delivery because the computer laboratories are not equipped with digital projectors and other presentation equipment. 


\subsection{ICT training of teachers}

The study shows that at the pre-tertiary levels, teachers are not trained to use ICT for teaching and learning, though the new curricula require that teachers integrate ICT into instruction across the curriculum. Visits to, and interviews with, teachers in some of the colleges of education reveal that the colleges of education are doing little to equip trainees with skills necessary to integrate ICT into teaching during their pre-service teacher training programmes. This study has also shown that the teaching universities are not doing much in this regard.

Only two departments in the UEW are offering programmes which train teachers to teach computer education in secondary schools. These departments enroll less than $5 \%$ of the university's students. The remaining $95 \%$ of the students enrolled by the university take only an introduction course in ICT in order to acquire basic computer literacy skills. This is a general course offered to all first year students to acquaint them with technology applications commonly found in educational settings. Students are taught basic skills in Word processing, Spreadsheets, PowerPoint, Web quest and the preview of educational software. In this introductory course, students are also lectured on ways of using ICT to enhance classroom instruction, communication and classroom management.

In addition to the general course in ICT taken by all students, certain departments offer additional course(s) that require the further use of the computer labs. The students in the Department of Mathematics Education take a 3-credit hour course in ICT each semester and therefore are adequately exposed to the teaching Mathematics with the use of ICT. Also students offering Art Education take an ICT course in Graphic Design and Technology and those in Music Education Department take ICT course in Music Technology for composition. All the same, it can be argued that over $80 \%$ of the UEW students, are not experiencing programmes that will offer them adequate opportunities to develop their pedagogical skills in integrating ICT.

\section{Discussion}

In our current system of education, little is done to develop global knowledge in one's discipline or "globalization literacy". The result is that our students' global literacy in the various subjects is low as evidenced in the country's performance in
TIMSS 2003 and 2007 (Anamuah-Mensah, et. al., 2004, 2008). The students perform poorly on tasks or problems that require application and reasoning skills because they have had little opportunity to develop their abilities to create, inquire, pose questions, probe, reflect, evaluate and learn how to learn. Most of these abilities however can be developed through the integration of ICT in teaching and learning.

The above findings corroborate what is observed in the Ministry of Education sponsored study on 'ereadiness of second cycle institutions in Ghana' (MOE, 2009). In the e-readiness study report, it is stated that the integration of ICTs for instructional purposes in Ghanaian schools is generally low and only a few schools have ICT tools and equipment that can be used to support this (MOE, 2009). Also according to the report, the low use for integration is seen as a direct link to the low skill levels in the area of integration by teachers, as well as limited access to ICT facilities as the computer laboratories are constantly in use.

\section{Conclusion}

Though Ghana's national curricula for the various subjects contain policy statements about the use of ICT in teaching and learning, the limitations imposed by inefficiencies in the curriculum design, inadequate number of computers in institutions, poorly trained educators and lack of Internet connectivity pose a major challenge to the implementation of the policy to integrate ICT into teaching and learning in Ghanaian schools. It is recommended, therefore, that the Ministry of Education should review the curricula at various levels of the educational system to ensure ICT pedagogical integration in their implementation and make available sufficient resources for ongoing training and support for teachers to model the new pedagogies and tools for learning.

\section{Research limitations and direction for further research}

As indicated above, the institutions/schools sampled were based on given guidelines. The selection is explicitly not meant to represent a national scale sample of all institutions, but rather to capture knowledge to be shared from schools that have computers and are attempting to apply them to teaching and learning. One should, therefore, interpret the findings above with caution in order 
to avoid unnecessary generalization of the findings to all institutions/schools in the country. One fruitful direction for further research which the study points is further investigation of how the official curriculum can be reviewed to assure ample opportunities for students to develop their strategic knowledge or 'global knowledge' as well as how teachers' classroom practice can be transformed to develop such knowledge at the various levels of the educational system.

\section{Acknowledgement}

Financial and material support for this study was generously provided by the International Development Research Centre (IDRC) in Canada through the Faculty of Education, University of Montreal, Canada, with the collaboration of ERNWACA on the PanAf project. I also wish to acknowledge the efforts of the following who are members of the Ghana PanAf research team based in UEW: Yidana, I, Hodzi, W., Tete-Mensah, I., TeteMensah, W., and Williams, J. B.

\section{References}

Anamuah-Mensah, J., Mereku, D. K. and GharteyAmpiah, J., (2008). TIMSS 2007 Ghana Report: Findings from IEA's Trends in International Mathematics and Science Study at the Eighth Grade, Ministry of Education, Accra.

Anamuah-Mensah, J., Mereku, D. K. and AsabereAmeyaw, A., (2004). Ghanaian Junior Secondary School Students' Achievement in Mathematics and Science: Results from Ghana's participation in the 2003 Trends in International Mathematics and Science Study, Ministry of Education Youth and Sports, Accra.

CRDD - Curriculum Research and Development Division (2007a). Teaching Syllabus for Information and Communications Technology (Core): Senior High School. Accra: Ministry of Education Science and Sports.

CRDD - Curriculum Research and Development Division (2007b). Teaching Syllabus for Information and Communications Technology (Core): Junior High School, Ministry of Education Science and Sports, Accra.
CRDD - Curriculum Research and Development Division (2007c). Teaching Syllabus for Information and Communications Technology (Core): Primary School, Ministry of Education Science and Sports, Accra.

ERNWACA - The Educational Research Network for West and Central Africa (2006). PanAfrican Research Agenda on the Pedagogical Integration of ICT, University of Montreal, Montreal.

Lehmann, J. (2007). The Diploma Disease: Does Education Suit Its Purpose? , Lausanne, Switzerland: IMD www.imd.ch (downloaded, February, 18. 2010).

Leu, D.J., Kinzer, C.K., Coiro, J.L. and Cammack, D.W. ,(2004). 'Toward a Theory of New Literacies Emerging from the Internet and Other Information and Communication Technologies'. In R.B. Ruddell and N. Unrau. (Eds.), Theoretical Models and Processes of Reading. Newark, DE: International Reading Association. Retrieved 23 February, 2009 from http://www.readingonline.org/newliteracies/leu/

Markauskaite, L., (2006). Towards an Integrated Analytical Framework Of Information And Communications Technology Literacy: From Intended to Implemented and Achieved Dimensions, Information Research, Vol. 11, No.3, paper 252 [Retrieved 23 February, 2009; from http://InformationR.net/ir/11-3/paper252.html].

Ministry of Education - MOE (2009). Report on eReadiness Assessment of Second Cycle Institutions in Ghana, ICT in Education Programmes Unit, Ministry of Education, Accra. 